\title{
INFORMAL AND SOCIALLY SITUATED LEARNING: GENDERED PRACTICES AND BECOMING WOMEN CHURCH LEADERS
}

\section{Introduction}

It has been suggested that in learning to become a (woman) leader, gender is relevant and (re)doing gender is fraught with ambiguity (e.g., Bryans and Mavin, 2003; Bierema, 2005; Cho et al., 2015; Mavin and Grandy, 2016; Phillips and Grandy, 2018; Stead 2014). Women face considerable systemic structural restraints enabled by patriarchy (Benschop 2009; Mavin and Grandy, 2016; Mavin, Grandy and Williams, 2014) and the complexities of women's leadership (e.g., discrimination, double bind, glass ceiling, glass cliff, second-generation bias) are well documented in management and organization studies (MOS) broadly. The ways in which women learn to lead, however, remain relatively unexplored and under-theorized, 'highlighting a lack of attention paid to the socially situated context in which learning experiences take place' (Stead and Elliott, 2012, 374). We extend this line of thinking and suggest that as a result of the neglect of understanding the socially situated context in which women learn to lead, the gendered practices which inform informal and social situated learning are hidden. Informal and socially situated learning can occur in the everyday experiences and processes of organizational life. Much of the learning that happens in organizations is unplanned, informal and often outside an individual's or group's conscious awareness (Marsick and Watkins 1990; Schürmann and Beausaert 2016; Slotte, et al.,, 2004). In this paper we advance understandings of the role of informal and socially situated learning in how women learn to lead and the gendered dynamics inherent in women's lived experiences of learning. This research is the result of an iterative process stemming from a larger study that explored the role of gender and identity in leadership and related development initiatives in faith-based organizations. The guiding research question for this paper, how does informal and socially situated learning and gendered practices impact the experiences of women learning to lead, 
emerged from a to-ing and fro-ing process between theoretical development and data analysis. Our research is underpinned by a social constructionist perspective and we look to the stories of 18 women-leader priests employed in three Christian-based groups in Canada. We use the term priest throughout to refer to ordained women leader priests, ministers and clergy associated with the Anglican Church of Canada, United Church of Canada, and the Roman Catholic Woman Priests of Canada (RCWP).

Our contribution here is two-fold. First, we extend understandings of the significance of informal and socially situated learning in becoming a (woman) leader (Bryans and Mavin, 2003; Cunliffe and Eriksen, 2011; Stead and Elliott, 2012). We also contend that informal and socially situated learning experiences can reveal gendered practices which contributes to gender inequalities and these experiences can inform the becoming of women leaders. We also build on research which acknowledges that gender bias can be subtle and invisible (Ely, Ibarra and Kolb 2011). We contribute by empirically demonstrating that informal experiences of learning can serve as a site for such invisible and unaccounted for gender bias and inform the becoming of women leaders. Second, we also contribute to the limited body of work in MOS that seeks to better understand gender dynamics of women's leadership in faith-based organizations (e.g., Page 2014; Stewart-Thomas 2010; Styhre 2014).

In what follows, we provide an overview of gender and women's leadership, and informal and socially situated learning as a gendered phenomenon. We also outline the research context. We detail the research design and present our findings through two themes, namely Informal and Socially Situated Learning as Inductive and Gendered, and The Jolt of Gender Discrimination in Informal Learning. We conclude our paper with a discussion of the implications of this research for learning and women's leadership. 


\section{Gender and Learning to Become a (Woman) Leader}

Gender is re-constructed through social activities and is understood here as the cultural making of perceived biological sex tied to 'rules' or associations of masculinity and femininity (Helms Mills and Mills 1999); historical, socially constructed, and embodied praxis bound by and unsettled within a web of complex power dynamics (Mumby and Ashcraft 2006; Stead 2014). Doing gender (West and Zimmerman 1987) is a dynamic, political and social process; 'an ongoing accomplishment grounded in interaction with others...activities that result in what is perceived to be expressions of masculine and feminine “natures” (West and Zimmerman, 1987)' (Mavin and Grandy, 2012, 220). Indeed, we also acknowledge that in doing gender there is agency and individuals can 'do gender well and differently' (Mavin and Grandy, 2013, 219). This means that women (and men) can do gender well by engaging in exaggerated expressions of femininity (or masculinity) and can do gender differently by engaging in masculinity (or femininity) and can do so simultaneously. This doing of gender well and differently can be 'seen' in how women (and men) enact leadership through multiple and simultaneous expressions of femininity and masculinity (Mavin and Grandy, 2012, 2013).

'Leadership and learning are often presented as gender neutral (Acker 1995; Fletcher 2004)', failing to acknowledge how some interests are privileged above others (Stead 2013, 65).

Learning to become a (woman) leader is complex. Women have to navigate through self-andothers' expectations of solidarity (e.g., supporting other women) and motherhood within cultures underpinned by 'competitive masculinity' (Mavin and Grandy, 2016, 1098) and 'where masculinist work ethics are internalized by both men and women' (Metcalfe 2008, 452). The practice (and theory) of Human Resource Development (HRD), the area accountable for learning 
in workplaces, has been critiqued because 'the dominant framework ... is underpinned largely by a masculinist organizing logic that emphasizes rationality, efficiency and the improvement of organizational performance' (Metcalfe 2008, 459). Moreover, critical HRD accounts contend that 'knowledge ... is understood to be contested...often concealed by illusions of homogenous identities' (Fenwick 2005, 228). As a result, what might be considered the more 'subjective' aspects of learning (e.g., emotions, embodiment) are often downplayed and the experiences (e.g., racism, sexism) of 'Others' (e.g., women) remain unvoiced in our understandings of learning to lead (Callahan 2007; Metcalfe 2008; Stead 2014).

Stead's (2014) work and that of others (e.g., Bierema 2005; Metcalfe 2008) highlight how formal HRD initiatives aimed to prepare leaders for their leadership roles can create and sustain gendered power relations in ways that negatively impact upon the becoming of women leaders. Stead (2014), for example, explored the experiences of women engaged in action learning as a part of a leadership development program. Her work vividly illuminates how the women participants' learning to become a leader was negotiated within a complex web of experiences linked to embodiment (e.g., height, voice, hair colour), age, social status, motherhood and type of organization (e.g., social enterprise). The women in Stead's (2014) research illuminate how formal action learning sets often involve addressing 'business' imperatives underpinned by masculinity (e.g., how to increase growth / profits). Such learning activities may not be relevant to all women participants and may serve to silence and disempower woman.

There is a growing body of research that argues most workplace learning occurs informally, incidentally, spontaneously, and unintentionally and that we need to better account for informal learning (e.g., Marsick 2006; Slotte et al., 2004; Schürmann and Beausaert 2016). Marsick (2006) and Marsick and Watkins (1990) explain informal and incidental learning. The former includes 
incidental learning, is typically not classroom based or highly structured, and learning rests primarily in the hands of the learner. Incidental learning is an unexpected outcome of some other activity, almost always takes place, and occurs often outside of conscious awareness.

Drawing from Marsick and Watkins (1990), workplace learning is grounded in experience and emerges through interactions and social structures. This means that workplace learning can happen through unplanned, everyday naturally occurring experiences and interactions and 'learning by doing' (Jeon and Kim 2012; Marsick 2006), where learning can be a 'side effect' of everyday problem solving (Slotte et al., 2004, 484; see also Marsick and Watkins, 1990). Marsick and Volpe (1999) summarize informal learning as: 'integrated with work and daily routines; triggered by an internal or external jolt; not highly conscious; often haphazard and influenced by chance; an inductive process of reflection and actions; and linked to the learning of others'.

Informal learning results in tacit knowledge acquisition and much of this type of learning happens outside an individual's conscious awareness (Kyndt et al., 2009; Schörmann and Beausaert 2016). Slotte et al., (2004) note that informal learning is often a 'hidden type of learning' (484).

Our particular focus here is in advancing understanding of how, through informal and socially situated learning, gendered practices are revealed, inequalities are reinforced and the becoming of women leaders is affected.

\section{Research context: A sacredly masculine site}

This research is part of a larger project which explored the role of gender in leadership in faithbased organizations and how various development initiatives might play a role in gender identity and leadership practices of women leader priests in Canada. We acknowledge that women leaders 
in this context face specific contextual complexities (e.g., theology of 'taint ${ }^{\text {') }}$ ) and that religious organizations are often 'sacredly masculine (Bock 1978)' (Page 2014, 295). However, it is because faith-based organizations are in many ways an 'extreme case' (Kreiner et al. 2009) of a gendered organization (Acker 1990 from Stewart-Thomas 2010) where we expect gender considerations to be particularly salient in the experiences of women leaders, that we believe it serves as a fruitful site to vividly illustrate how informal and socially situated learning might reveal (hidden) gendered practices. Following Elliott and Stead $(2008,160)$ we suggest our work 'is distinctive in making visible leadership experiences that are occurring in alternative settings'.

We looked to the experiences of women leading in three Christian-based organizations: Anglican Church of Canada; United Church of Canada; and Roman Catholic Women Priests (RCWP). Each of these organizations employ different paths for becoming priests. Most involve some approval process at the congregation or higher institutional level (e.g., diocese) before the individual is engaged in formal divinity training. That formal divinity training may be in the form of a University degree, but not always. As historical context, the first woman minister / priest was ordained in the United Church of Canada in 1936, and in the Anglican Church of Canada in 1976 (with the first women elected as bishops in the 1990s). Of the 3,516 ordained ministers of the United Church in 2014 38\% were women, and 295 diaconal ministers, of which 92\% were women (UCC 2016). Ordained ministers are primarily responsible for the ministry of the sacraments, while diaconal ministers are primarily responsible for education and community ministry. It has been argued that diaconal ministers are marginalized, relative to ordained ministers, within the structure and practices of the church (Heuer 1992). Approximately 35\% of active clergy (406 out of 1139) and $21 \%$ of retired clergy (369 out of 1750) in the Anglican Church of Canada are women (Folkins 2016). Nine of 41 bishops (22\%) listed as active or bishops-elect are women (ACC 2016). The 
Roman Catholic Church does not ordain woman as priests to this day, however, the Roman Catholic Women Priests (RCWP) is an international movement within the Roman Catholic Church premised upon a feminist model. It operates as a loosely connected, non-hierarchical and nonfinancial structure. While RCWP acknowledge that in ordaining women as priests and bishops 'within' the Roman Catholic faith, they are violating the Church's Canon Law 1024, however, they argue that their ordinations are 'valid' because they have been ordained in apostolic succession within the Roman Catholic Church (e.g., ordained by a Roman Catholic bishop) (RCWP 2015). The first were ordained in 2002 and in Canada there are nine priests and one bishop listed on the RCWP Canada website (RCWPC 2016).

The subtle and not so subtle gender bias experienced by women leaders in faith-based organizations has been documented in practice and in research. In delivering a keynote speech at the $40^{\text {th }}$ anniversary of the ordination of women in the Anglican Church of Canada, Canon Judy Rois, executive director of the Anglican Foundation of Canada, talked about the ongoing struggles that women leaders in the church confront. 'The progress we've made over those years has made life significantly better than it was for our mothers and grandmothers, but oh my, it has been a very hard row to hoe... all of us know the strain of a white collar around our neck, and all of us know the sting and pain of opposition' (Rois, quoted in Folkins 2015, para. 3). Such 'strain' is well documented in studies of women leaders in various faith-based organizations. Not unlike other professions historically dominated by men (see for example, Germain et al., 2012), women entering this profession can face unwelcoming cultures (from other clergy and congregation members), sex-role stereotypes (e.g., expected to do more care work), slower advancement and fewer opportunities for promotion, and lower salaries (Adams 2007; Bagihole 2003, 2006; Page 2014; Stewart-Thomas 2010; Styhre 2014). In essence, they face vertical (e.g., limited 
advancement opportunities), horizontal (e.g., more likely to be appointed to rural parishes or nonparish posts such as hospitals) and contractual (e.g., more likely to be hired on a part-time basis) segregation (Stewart-Thomas 2010).

The findings from our larger study revealed that very little of the formal learning initiatives and experiences of these women leaders accounted for gender - by most accounts these were gender blind or genderless. The exception to this could be seen in the accounts of the two participants from the RCWP. RCWP's philosophy and related formal HRD are founded upon feminist principles. RCWP strives to account for the gendered power relations which are embedded in the institution of the Roman Catholic Church. RCWP challenges the masculinist, hierarchical and financial model of the Roman Catholic Church. As such, the movement, structure and formal learning initiatives are inclusive of gender considerations (e.g., modules which focus upon alternative interpretations of Biblical passages to support the rightful ordination of women; training in effective consensus-based decision making).

Despite the absence of explicit recognition of gender in formal learning initiatives for most of these leaders, their stories reveal that their informal learning was marked by gendered practices and inequities that guided how they learned to lead in this context. In collaborative discussions between the authors, we re-read the transcripts with a closer look at how these gendered practices

were concealed and revealed through informal and socially situated learning processes and the implications of this for the women participants' leadership.

\section{Research design}

For this research we adopt a becoming ontology and a social constructionist perspective, where we understand individual experiences as occurring within a 'web of relationships' (Cunliffe 2008, 
129). As researchers, our engagement with participants, the transcribed interviews and with each other reflect an ongoing process of co-construction of meaning.

A qualitative approach facilitated the surfacing of rich and reflective accounts from the women leaders. We were guided by feminist principles, "placing emphasis on the importance of experience and particularly women's experiences (Griffin 1995)' (Bryans and Mavin, 2003, 112). Semi-structured interviews were conducted by the first author with 18 women leader priests in Canada. The interviews were audio-taped and subsequently transcribed.

The group of women leaders was diverse in regards to the faith based organizations in which they led, as well as the length of time since ordination (e.g., ranging from five years to 30 years), geographic location in Canada (e.g., women leaders were practicing in six different provinces), formal training (e.g., Masters of Divinity Studies, locally ordained), and position (e.g., associate priests, senior priests / rectors, bishops, archdeacons). Of the 18 participants, two indicated that they did not want to be quoted directly.

The women leaders were made aware (via informed consent forms) that there was some risk of being identified in participating in the research study even if they chose to be referred by a pseudonym. While many of the women indicated on their informed consent forms that they were willing to be identified by name, parish and denomination, given the relatively small number of women interviewed and that any direct reference to their denomination might compromise the anonymity of any one of the participants, participants are referred to here only by pseudonyms and how long they have been ordained.

In designing the interviews, we asked participants a number of questions related to their career journey and biographical details, experiences of formal and informal training and education, challenges they faced as a woman leader and if that affected how they enacted their leadership as 
a woman leader in the church, and the types of resources available to them (people or otherwise) that were available to them as women leaders in the church.

The first author took the lead in the data analysis and engaged in an iterative process of 'literal' and 'interpretative' readings (Mason 2002). Following this, in collaborative discussions with the second author, both authors re-read and analyzed accounts, first with a focus upon gender and identity as it related to learning to lead (the aim of the larger study). This process led to initial themes revealing how women leaders in the church lead (e.g., boundary making and marking; confronting the gender disadvantage; doing gender well and differently). As we continued to reread the data as it related to these initial themes, we were struck by participants' accounts of the informal and incidental learning that informed how they led. While most participants discussed that there was no or very little coverage of gender in their formal training, their learning by doing revealed that gendered practices were hidden and guided their informal learning to become women leaders. We then re-read the data and focused upon how informal and socially situated learning happened and how gendered practices were concealed and revealed through these learning experiences. It was through this process that we also interpreted that not all of the women leaders' informal learning was marked by gendered practices and we describe this in the first theme to be discussed, Informal and Socially Situated Learning as Inductive and Gendered. We also interpret that the gendered nature of becoming women leaders and its relationship to informal and socially situated learning can be illustrated through a second theme namely, The Jolt of Gender Discrimination in Informal Learning.

\section{Informal and socially situated learning as inductive and gendered}


Participants acknowledge that formal learning initiatives cannot account for everything they needed to know as a (woman) leader. Learning to lead in this context is informed as much by incidental, spontaneous and unintentional experiences as it is by their experiences of / from formal training. Their learning is inductive in nature whereby participants' reflection and action intertwine to inform their becoming a (woman) leader in this context. Informal learning is also a social process for these leaders, where they learn from and with others.

In reflecting on a question about how her formal training for ministry prepared her, Tanya focused on the sense of isolation that came with leading. She indicated that her learning involved living it in order to understand that, something for which formal training could not prepare her. 'No, not at all and I mean they certainly talked about the sense of isolation [in ministry training] and what it's like to live in a fishbowl, but I never truly understood it until I was there myself and even if they had attempted to prepare us for that, I certainly still wasn't prepared for that' (Tanya, ordained for five years).

Others talked about how learning by doing was important and that in observing others and in interactions with others they learned to lead. These informal learning experiences provided opportunities to reflect-in-action in becoming leaders. When asked how formal learning or other work she has done prepared her for ministry, Patricia explicitly acknowledged the importance of informal dialogic learning, specifically peer-to-peer discussion, support and mentorship.

Some of the continuing education pieces have been helpful in terms of that [preparing her for ministry] and the most helpful ones were informal. Sometimes when my colleagues and I get together and we spend a couple days reading what we want to read and going through the material together and talking about what it means to be a minister and to be a leadership 
in the church. I think that feeds me the most just in terms of church leadership. Colleague contact and just peer discussion is just the best thing I think (Patricia, ordained for 25 years).

The informal learning of these women church leaders was not always experienced as a gendered process, although at times it was. The informal learning experiences that revealed gendered practices were often the result of shared learning passed along by other women leaders, lessons never addressed in their formal ministry training. For many of the participants, informal mentorship by other women leaders served as a hidden type of learning (Slotte et al., 2004) or a resource-bank from which they could draw upon when they needed it in the practice of their own leadership.

The shared experiences of another woman priest helped to prepare Eliza for what she might encounter as a woman priest. Eliza's informal mentor painted a particularly vivid picture of the gendered nature of leading in this context. Eliza felt the insights of this colleague better prepared her for her own journey in learning to become a woman leader.

[She told me] some men will not receive communion from a woman. Absolutely refused, unless it was a male minister serving... she raised awareness for me of the sexism that is out there unrecognized by the average person in the pew ... She said, 'when I go away, I'm of course still working for the church outside of the local area'. She said, 'I come home, the freezer is almost full' he [her husband, also a minister] went out to eat every evening, because 'poor guy his wife's away'. She said, 'I'm doing the same job, but if he goes away, people could care less if I starved away in the dark' ... I do believe that male ministers are invited to eat more frequently than female ministers because we're suppose to cook for ourselves... Even when we're doing the same amount of work and in some cases, more so. It's perceived 
differently, the whole societal context is different and sharing those experiences are important (Eliza, ordained for 15 years].

The experience of learning how the enactment of leadership was gendered was also an inductive process of reflection-in-action (Schön 1983) that required what we interpret as tolerance and courage. As put by Sharen (ordained for 20 years), 'sexism is not dead, and woman leaders need to be prepared to stand their ground, to walk away or, call somebody [out] on that'. In talking about calling out gender bias, Jane expressed how many leaders do not recognize a gender blindness that informs the becoming of a woman leader in this context. Jane struggled with finding ways to 'mend their [men priests'] reality' so they became more aware of their gender blindness. She recounted two stories about a particular man priest and in both instances Jane called out what she experienced as gendered and 'inappropriate'.

She [another woman priest] had a new hairstyle, different from probably the last time we saw her. Right in the middle of all us sitting around a table during a meeting, this priest spoke up and called her by name. He looked at her and said 'what have you done, is that a new hairstyle you've got?' I never said anything then at that point, but when the meeting was over I spoke to the female and I said 'you know that was most inappropriate and that's not acceptable'. It's one thing if they want to comment on your hair one to one to your face, that's whatever, but she was writing notes at the time when he spoke to her. A little while later I had my opportunity and I said 'listen, you better be careful cause one of these days if you keep speaking like that [to other women priests] in a public place you could be up on charges because that is unacceptable (Jane, ordained for 24 years). 
One day he [man priest] said to me, 'Jane, does that earring actually go through your ear?' I made whatever kind of a comment to him and then he made a similar comment a second time. The second time he did it was in a meeting with people sitting around the table and I looked at him and I called him by name across the table. I said 'do you have an earring fetish?' He never again commented on my earrings or anything else that I would consider inappropriate (Jane, ordained for 24 years).

Jane's recollections are illustrative of how the informal learning process is inductive and results from a process of reflection-in-action. We interpret that for Jane 'mending the reality' of those blind to gender requires an awareness of the gendered practices, support for others experiencing it, and courage to reveal the practices, speak out and hold others accountable. As such learning to become a leader can be gendered and that this learning can be spontaneous, incidental and a side effect of everyday problem solving (Slotte et al., 2004).

\section{The jolt of gender discrimination in informal learning}

Many of the woman participants in this study were taken by surprise or jolted when they experienced overt gender discrimination and this triggered their informal learning that leading was indeed a gendered process. Several talked about how women were held to higher expectations than men and criticized more severely, especially when they made a mistake. In her research with senior women leader priests in the Church of England, Bagilhole (2006) referred to these environments as 'hostile cultures' (118) where 'women hold different posts, do different types of work in different propositions to men, and take on different roles' (121) (e.g., doing more pastoral care work). Several women talked about despite the fact that women have been ordained in some denominations for more than 75 years (e.g., United Church), congregation members are still 
unsettled by the presence of women priests. This discomfort manifests through overt discrimination (e.g., refusing to take communion from women leaders at the altar). Sheila (ordained for 30 years) talked at length about the overt gender discrimination she confronted not only early in her career but throughout her career. These lived experiences were a jolt, but an important part of her learning to become a woman leader in this context.

You come up to the church to receive Communion, bread and wine. And people would come up and if I was serving bread or wine on one side, they would take the other side, the side they wouldn't have to receive from me. There were lots of people, they would just call ahead of time to see who was providing at Communion and if I was providing they wouldn't come that Sunday, or they would go somewhere else. (Sheila, ordained for 30 years).

In response to asking her how she managed through these experiences, Sheila expressed, 'you just figure it out yourself, you just find your own support systems, you just find your own mentors'. In this way, Sheila's informal learning was part of her becoming a woman leader and was an iterative, social and gendered process.

Janeen, ordained for five years, indicated that she still feels that she isn't always taken seriously by priests affiliated with other denominations, as well as by members of the community outside of her parish. One member of an ecumenical community committee 'knows I'm a priest, but she calls me little girl every time we meet".

For others, it was in their pursuit of career advancement that they were confronted with and 'alarmed' (Deborah, ordained for 10 years) by such overt gender discrimination. Making sense of these experiences is a social process informed by the support of colleagues who assist in this 
sensemaking informal learning process. Deborah was challenged by someone in a higher position of formal authority for a choice she made earlier in her career, a choice that was considered to be of a gendered nature (read: obligation of femininity). This choice permitted her to be closer to her mother during a period when her mother was ill. She described being 'thrown' by comments that revealed overt engrained gendered practices that would hold her (and likely other women) back when she expressed interest in her career advancement. When faced with such gender discrimination, she 'called it out' and relied on the support of other colleagues to work through how these experiences informed her own learning to lead in this context.

As we're trying to break into larger churches, that's where the sex of women is starting to show up and I'm kind of alarmed by it and thrown by it. I also have a lot of support from other colleagues here to help with that and to help be confident in interpreting things as well. For example, I spent several months [a couple of years before] back in [the area where she grew up] to be closer to my mom [because she was ill]. When I came back to this diocese I sat down with the bishop and I said 'you know I have now run two parishes and they've both grown under my leadership, I've only done team ministry in this diocese, it's time for me to have my own parish and I'm gonna hold out for it'. One of the Bishops said 'how do we know you're not gonna run off if your mother gets sick again?' So I said 'I'm gonna do it the way we all do when our parents are sick, we're going to live our lives and them when something happens, we figure out what we're going to do then...' He said 'I just know cause my sister lived close to my mom and she goes like night and day and I know how hard it would be for my sister if she had to be far away from my mother'. I felt like saying 'I know 
how to make it easier for your sister, go visit your mother you asshole'. Are you kidding me? (Deborah, ordained for 10 years).

Career pursuits of women leaders like Deborah can be thwarted because of engrained gendered practices, practices which surface through incidental and informal learning experiences. Indeed, some women leader priests felt they were punished for what we interpret as violating gender-role stereotypes. Further, when asked to describe the expectations for woman leaders and if they were the same for both men and women priest leaders, some felt the expectations were the same, but a number offered various examples of how the expectations were different in ways that disadvantaged women. Carole's (ordained for 27 years) account offers insight into how she was 'punished' for violating sex-role stereotypes as a woman (e.g., pursuing higher education, paying someone to assist with housekeeping) and as a woman leader (e.g., having childcare responsibilities) in the church. She reveals that congregations can have taken for granted assumptions of heterosexuality; the role of Priest is one held by a (heterosexual) man with a wife to handle life responsibilities such as caring for children. Women leader priests violate these deeply engrained assumptions, a violation which in turn, can result in overt and subtle forms of discrimination:

I had started on a Doctor of Ministry program, with the congregation's blessing, and the treasurer said 'if we're paying you that much that you can afford to, to go back to school, then we're paying you too much'. So money got cut out of my salary and then [later], I had two little kids and a busy life and we hired somebody to come in and clean our house once, twice a month and the treasurer said again 'if you can afford to hire someone to clean for 
you, we must be paying you too much' and so they cut more money out on my salary ...it was a really demeaning place to be....With a man pastor, they [congregations] expect that the wife will come along and that the wife will take care of the children and that will be fine and all will be well. But I was as a mom in the Parish ...I had both of the kids with me and had to literally hire a babysitter to meet me at the church every Sunday. ...I know my gender played a role...there would be times when you know the church council president would say 'you know if you were a man you would handle this differently' (Carole, ordained for 27 years).

Carole's lessons about what it means to be a woman leader as it relates to the insights above were not learned through formal training, they were triggered by an external jolt (or several jolts) and in effect what Slotte et al. (2004) describe as a side effect of everyday problem solving. Carole confronted gendered discrimination which surprised her and triggered her informal learning.

In summary, the informal and socially situated learning of becoming a woman leader is marked by gendered blindness and gendered practices which, when encountered, can jolt these woman leaders. These unplanned and everyday naturally occurring interactions become part of their learning by doing. The experiences of these women leaders illustrate how learning to lead is informed as much by informal and socially situated experiences (e.g., peer to peer dialogic conversations; informal mentoring) as it is by formal HRD initiatives. The informal learning of these women leaders also reveals how in learning to lead gender is relevant and this is mostly hidden and unaccounted for in formal HRD initiatives. The accounts of these women leaders uncovers the need for organizations, and in particular HRD practitioners, to take stock of informal 
and socially situated learning and redress the gender blindness and gendered practices which can underpin that learning.

\section{Discussion and conclusions}

In this paper we set out to explore how informal and socially situated learning and gendered practices impact the experiences of women learning to lead. For these women leaders a considerable part of their learning (to become a leader) occurred outside of formal training activities and practices. This learning often remains hidden in emergent, unplanned, incidental and unspoken experiences.

Exploring experiences of informal learning provides an opportunity for us to better understand how learning to become a woman leader is tied to power dynamics whereby certain everyday experiences serve to advantage some and disadvantage others (Fenwick 2005). Here we place women leaders' experiences at the forefront of our study and illuminate 'how women leaders learn from their lived experience of leadership about the ways in which gender and power operate' (Stead 2013 75). We respond to Stead's (2013) call to find ways to 'reveal women's lived experiences of learning leadership' (76). In interactions with others, these women leader priests learn to negotiate the complexities of becoming leaders. Following Bryans and Mavin (2003) in their work on women learning to become managers, this research serves to offer space for what might otherwise be silenced experiences.

For women church leaders, learning to become a leader comprises informal and relational processes informed by experiences within gendered social and cultural contexts (see also Stead and Elliott, 2012). In this way, we extend understandings leadership as a relational, contextual, 
and social learning process (Bryans and Mavin, 2003; Cunliffe and Eriksen, 2011; Stead and Elliott 2012).

Our research also offers insights into how women leaders learn to become leaders in a particular context and how gender and power intertwine to inform those experiences. The foundations of the RCWP place gender front and center. The organization, movement and the RCWP women leader priests are marked by controversy within the institution of the Roman Catholic Church. We would expect the gendered nature of learning to be particularly salient in their experiences. Interestingly, the United Church and Anglican Church have ordained women for some time and yet, these women leaders also continue to face a number of systematic barriers that affect how they lead and how they learn to lead. Our research contributes to understanding and exposing the challenges and complexities faced by women leaders in a particular context, one historically marked by disadvantage (e.g., Adams 2007; Bagihole 2003, 2006; Page 2014; StewartThomas 2010; Styhre 2014). Further, by including their voices we contend that we are broadening the diversity and therefore remit of MOS. Through a gender lens we are able to interpret their accounts and highlight the gendered nature of learning and leadership and the 'subtleties that make working lives so fraught for women are "entrenched in modernity's presumptions of how to do [leadership] work" (Harding et al., 2013: 58)' (Mavin and Grandy, 2016, 1115).

Our research focused upon the informal and socially situated learning of these women church leaders and the gendered nature of this learning. We did not discuss how this learning informs their leadership styles, but we are left wondering how this informal learning might impact leadership styles. Specifically, do women lead differently than men in this context as a result of the gendered nature of their informal learning experiences, and should they learn different skills / competencies to perform effectively in this context? In a context where caring is critical to the 
work of leaders, future research should examine such questions. Such an avenue could advance debates regarding women enacting more transformational (feminine?) leadership behaviours than men (Eagly et al., 2003) and Druskat's (1994) work on how context matters in the enactment of transformational leadership behaviours by women in the church setting (e.g., in all women church settings, women church leaders are more likely to display transformational leadership behaviours). It could also surface provocative questions about the need to change organizational cultures, rather than women adapting their styles to meet the embedded expectations of organizations (Druskat, 1994).

Finally, as noted by one of the women leaders, 'sexism is not dead' (Sharen) and based on the accounts of these women little attention and few supports are directed to addressing this in formal and informal HRD initiatives. While the contextual considerations have important implications for women in the church setting, we suggest that many of the insights are transferable more broadly (e.g., professions where 'work' is a vocation or calling such as social work and teaching). Following Metcalfe (2008) and Stead (2014) we suggest that learning scenarios must look different to enable space for gender. Organizations must first acknowledge that gender is relevant, and then through formal HRD efforts offer knowledge and supports (e.g., leadership development programs, mentorship programs, training for board and organizational members) that challenge sex role stereotypes and foster HR practices and cultures that work to remove the disparities. In regards to informal learning, HRD practitioners need to recognize and tap into informal learning and the hidden gendered practices that it can reveal. In turn, changes to formal HRD initiatives (e.g., action learning sets, leadership development programs) need to incorporate these insights and lessons. Further, HRD practitioners need to support informal learning so that leaders have outlets through which to sense make such gendered experiences (e.g., online 
resources / networks; diverse role models). For these women, having outlets through which share experiences, learn from each other, and learning to reflect-in-action aided in their constructive informal learning. Future research should explore further the types of informal learning initiatives and systems which acknowledge and best support women learning to lead in (gendered) organizations.

\section{Notes}

1. The 'theology of taint' refers to the theological argument that women should not be ordained in the Church of England because Jesus only ordained and gave authority to men. The term was used by the Archbishop of York, John Sentamu, in his statement celebrating the consecration of the first woman bishop, Libby Lane, to the Church of England in 2015 (Sentamu, 2015).

\section{References}

Acker, J. (1995) "Feminist Goals and Organizing Processes." In Feminist Organizations: Harvest of the New Women's Movement, edited by M.M. Ferree and P.Y. Martin, 137-144. Philadelphia, PA: Temple University Press.

Adams, J. (2007) "Stained Glass Makes the Ceiling Visible: Organizational Opposition to Women in Congregational Leadership" Gender \& Society 21 (1): 80-105.

ACC (Anglican Church of Canada) (2016) "Bishops of the Anglican Church of Canada" Accessed January 1, 2017. http://www.anglican.ca/about/bishops/

Bagilhole, B. (2006) "Not a Glass Ceiling More a Lead Roof. Experience of Pioneer Women Priests in the Church of England" Equal Opportunities International 25 (2): 109-125.

Benschop, Y. (2009) “The Micro-politics of Gendering in Networking” Gender, Work \& Organization 16 (2): 217-237. 
Bierema, L. (2005) “Women's Networks: A Career Development Intervention or Impediment" Human Resource Development International 8 (2): 207-224.

Bryans, P. and Mavin, S. (2003) "Women learning to become managers: learning to fit in or to play a different game?", Management Learning, Vol. 34 No. 1, pp. 111-134.

Callahan, J. (2007). "Gazing into the Crystal Ball: Critical HRD as a Future of Research in the Field" Human Resource Development International 10 (1): 77-82.

Cho, Y., N. Kim, Lee, M.M. Lim, J.H. and Park, YY. (2015) “South Korean Women Leaders' Struggles for Work and Family Balance" Human Resource Development International 18 (5): $521-537$.

Cunliffe, A. (2008) “Organization Theory” London, England: Sage.

Cunliffe, A., and Eriksen, M. (2011) "Relational Leadership" Human Relations 64 (11): 14251449.

Druskat, V. (1994) “Gender and leadership style: Transformational and transactional leadership in the Roman Catholic Church" Leadership Quarterly 5 (2): 99-119.

Eagly, A., Johannesen-Schmidt, M., and van Engen, M. (2003) “Transformational, transactional, and laissez-faire leadership styles: A meta-analysis comparing women and men" Psychological Bulletin 129 (4): 569-591. .

Elliott, C. and Stead. V. (2008) “Learning From Leading Women's Experience: Towards a Sociological Understanding" Leadership 4 (2): 159-180.

Ely, R.J., Ibarra, H. and Kolb, D.M. (2011) “Taking Gender into Account: Theory and Design for Women's Leadership Development Programs" Academy of Management Learning and Education 10 (3): 474-493. 
Fenwick, T. (2005) "Conceptions of Critical HRD: Dilemmas for Theory and Practice" Human Resource Development International 8 (2): 225-238.

Fletcher, J.K. (2004) "The Paradox of Postheroic Leadership: An Essay on Gender, Power, and Transformational Change" Leadership Quarterly 15 (5): 647-661.

Folkins, T. (2016)“40 Years After the First Ordination of Women, Achievements and Challenges” Anglican Journal, December 2. Accessed January 1, 2017. http://www.anglicanjournal.com/articles/40-years-after-the-first-ordination-of-women$\underline{\text { achievements-and-challenges }}$

Germain, M.L., Ronan Herzog, M.J. and Rafferty Hamilton, P. (2012). "Women Employed in Male-dominated Industries: Lessons Learned from Female Aircraft Pilots, Pilots-in-training and Mixed-gender Flight Instructors" Human Resource Development International 15 (4): 435453.

Griffin, C. (1995) “Feminism, Social Psychology and Qualitative Research" The Psychologist 8 (3): 119-121.

Helms Mills, J. and Mills A.J. (1999) "Rules, Sensemaking, Formative Contexts and Discourses in the Gendering of Organizational Culture" In Handbook of Organizational Culture and Climate, edited by N. Askernasy, C. Wilderom and M. Peterson, 55-70. Thousand Oaks: Sage. Heuer, K. (1992) “So Tell Me Again, What is a Diaconal Minister?” Major Project. St. Stephen's D.Min Program. Accessed January 1, 2017. http://ducc.ca/wp-content/uploads/Heuer-Kay-sotell-me-again-what-is-a-diaconal-minister.pdf

Jeon, K. and Kim. K. (2012) "How do organizational and task factors influence informal learning in the workplace?" Human Resource Development International 15(2): 209-226. 
Kreiner, G., Hollensbe, E. and Sheep M. (2009) "Balancing Borders and Bridges: Negotiating the Work-home Interface via Boundary Work Tactics" Academy of Management Journal 52 (4): $704-730$.

Kyndt, E., F. Dochy and B. Brand (2009). "Learning conditions for non-formal and informal workplace learning" Journal of Workplace Learning 21(5): 369-383.

Marsick, V. (2006) "Informal strategic learning in the workplace" In J. Streumer (Ed) Work Related Learning, 51-69, Netherlands: Springer.

Marsick, V. and M. Volpe. (1999) "The nature and need for informal learning" Advances in Developing Human Resources 1(3):1-9.

Marsick, V. and K. Watkins (1990) "Informal and Incidental Learning in the Workplace" New York: Routledge.

Mason, J. (2002) “Qualitative Researching”. London: Sage.

Mavin, S. and Grandy, G. (2016) “A theory of abject appearance: Women elite leaders' intra gender 'management' of bodies and appearance" Human Relations 69(5), 1095-1120. (note: Online First 2015. DOI: 10.1177/0018726715609107.

Mavin, S. and Grandy, G. (2013) "Doing gender well and differently in dirty work" Gender, Work \& Organization, 20 (3), 232-251. (note: Online 4 August 2011. DOI: 10.1111/j.14680432.2011.00567.x)

Mavin, S. and Grandy, G. (2012) "Doing gender well and differently in management" Gender in Management: An International Journal, 27(4), 218-231

Mavin, S., Grandy, G. and Williams, J. (2014) "Experiences of women elite leaders doing gender: intra-gender micro-violence between women in management" British Journal of Management 25(3), 439-455. 
Metcalfe, B. (2008) “A Feminist Poststructuralist Analysis of HRD: Why Bodies, Power and Reflexivity Matter” Human Resource Development International 11 (5): 447-463.

Mumby D.K. and K.L. Ashcraft (2006) “Organizational Communication Studies and Gendered Organization: A Response to Martin and Collinson” Gender, Work and Organization 13 (1): $68-90$.

Page, S. J. (2014) "The Scrutinized Priest: Women in the Church of England Negotiating Professional and Sacred Clothing Regimes" Gender, Work and Organization 21 (4): 295-307.

Phillips, T. and Grandy, G. (2018) "Women leader/ship development: mindfulness and wellbeing” Gender in Management: An International Journal, 33 (5):367-384, https:// doi.org/10.1108/GM-11-2016-0.

RCWP (Roman Catholic Women Priests) (2015) “About us.” Accessed December 15, 2016. http://romancatholicwomenpriests.org/index.php

RCWPC (Roman Catholic Women Priests Canada) (2016) “Contact us.” Accessed December 15, 2016. http://rcwpcanada.x10.mx/docs/DirectoryOfPriests.pdf

Schön D. (1983) “The Reflective Practitioner: How Professionals Think in Action" New York: Basic Books.

Schürmann, E. and Beausaert, S. (2016) "What are the drivers for informal learning?" European Journal of Training and Development 40(3): 130-154.

Sentamu, J. (2015) "Forthcoming Consecrations" Accessed December 31, 2016. http://www.archbishopofyork.org/articles.php/3204/forthcoming-consecrations

Slotte, V., P. Tynjälä and T. Hytönen (2004) “How do HD practitioners describe learning at work?” Human Resource Development International 7(4): 481-499.

Stead, V. (2014) "The Gendered Power Relations of Action Learning: A Critical Analysis of 
Women's Reflections on a Leadership Development Programme" Human Resource Development International 17 (4): 416-437.

Stead, V. (2013) "Learning to Deploy (In)visibility: An Examination of Women Leaders' Lived Experiences" Management Learning 44 (1): 63-79.

Stead, V. and C. Elliott. (2012) "Women's Leadership Learning: A Reflexive Review of Representations and Leadership Teaching” Management Learning 44 (4): 373-394.

Stewart-Thomas, M. (2010) “Gendered Congregations, Gendered Service: The Impact of Clergy Gender on Congregational Social Service Participation" Gender, Work and Organization 17 (4): 406-432.

Styhre, A. (2014) "Gender Equality as Institutional Work: The Case of the Church of Sweden" Gender, Work and Organization 21 (2): 105-120.

UCC (United Church of Canada) (2016). "United Church Statistics” Accessed January 1, 2017. http://www.united-church.ca/sites/default/files/resources/united-church-statistics.pdf

West, C. and D.H. Zimmerman (1987). “Doing gender” Gender \& Society 1 (2): 125-51. 